\title{
CULTURAL LANDSCAPE AND BUILT HERITAGE IN PORT CITIES OF THE RECÓNCAVO BAIANO: A STUDY FOR PRESERVATION
}

\section{Luís Cláudio Requião da Silva}

p. $01-24$

Como citar este artigo:-

SILVA. L, C, R. Cultural landscape and Built Heritage in port cities of the Recôncavo Baiano: A study for preservation

Revista Eletrônica: Tempo - Técnica - Território, v.6, n.2 (2015), p. 1:24

ISSN: 2177-4366. DOI: https://doi.org/10.26512/ciga.v6i2.21936

revista

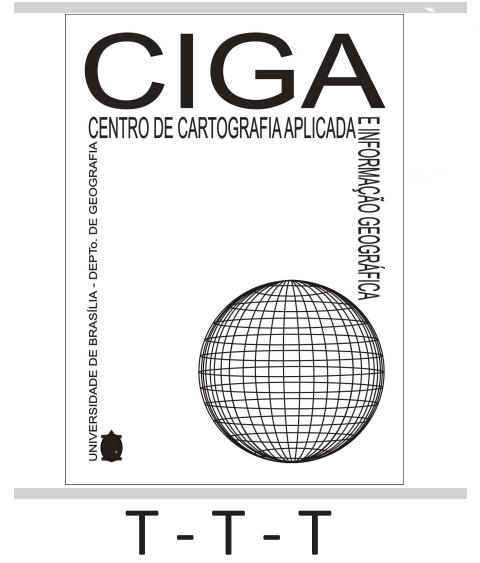

Revista Eletrônica: Tempo - Técnica - Território,

V.6, N.2 (2015), 1:24

ISSN: 2177-4366

DOI: https://

doi.org/10.26512/

ciga.v6i2.21936
Disponível em: http://periodicos.unb.br/index.php/ciga/

Este obra está licenciado com uma Licença Creative Commons Atribuição-NãoComercial 4.0 Internacional. 


\title{
CULTURAL LANDSCAPE AND BUILT HERITAGE IN PORT CITIES OF THE RECÔNCAVO BAIANO: A STUDY FOR PRESERVATION
}

\author{
Prof. Dr. Luís Cláudio Requião da Silva \\ Professor Assistente "B" da Universidade do Estado da Bahia - UNEB
}

luisrequiao6@gmail.com

\begin{abstract}
This article deals with the urban dimension of the heritage and is located within the Historical Urban Geography with the emergency of a regional spatial narrative from the analysis of the cultural landscape of seven port historic cities of the Reconcavo Baiano, region which is located in the vicinity of All Saints Bay, state of Bahia, Brazil.

Therefore, we declare that there was a simultaneous production of urban areas in the production process and spatial organization of cities Jaguaripe, Cachoeira, São Francisco do Conde, Maragogipe, Santo Amaro, Nazare and St. Felix, throughout the 19th century, detected by the similarity of the aesthetic and structural standard of its architectural and urban sets and the temporal concomitance in their setting-up, materialized in urban heritage, culminating in what we call regional spatial narrative.

It searches comprehension of this narrative, focus work on local and regional scales, articulated to the socio-economy, the history and urban production. The built heritage is recognized as the main element that characterizes the cultural natural of material, whose symbolic expression is multiscale (local and regional) and is expressed in the cultural landscape / urban of the cities. The ultimate goal is to propose safeguarding the Recôncavo Baiano region, by being indicated to obtain the title of "Cultural Landscape of Humanity", focusing mostly on the historical and symbolic support of the built heritage of these cities in the cultural formation context and identity of that region.
\end{abstract}

KEY WORDS: Regional spatial narrative; cultural landscape; built heritage; Port historic cities; Reconcavo Baiano

RESUMEN: Este artículo aborda la dimensión urbana del patrimonio y se encuentra dentro de la geografía urbana histórica con el surgimiento de una narrativa espacial regional a partir del análisis del paisaje cultural y urbana de siete ciudades históricas de la Recôncavo Baiano, región puerto situado en los alrededores de la Baía de Todos os Santos, estado de Bahía, Brasil. En este sentido, nos dicen que hubo una producción simultánea de territorios urbanos en el proceso de producción y organización espacial de las ciudades de Jaguaripe, Cachoeira, São Francisco do Conde, Maragogipe, Santo Amaro, Nazaré y São Félix, durante todo el siglo XIX, detectado por la similitud de los patrones estéticos y estructurales de sus conjuntos arquitectónicos y urbanísticos y por la construcción de la misma concomitancia temporal se materializó en patrimonio urbano, culminando en lo que llamamos narración espacial regional. La búsqueda de la comprensión de esta narrativa, el enfoque de trabajo en las escalas locales y regionales, había articulado de la economía social, historia y producción urbana. Los edificios son reconocidos como elemento principal que caracteriza a la naturaleza del material cultural, cuya expresión simbólica es multiescalar (local y regional) y se expresa en el panorama cultural de estas ciudades urbanas /. El objetivo final es proponer la protección de la región del Recôncavo, a través de la indicación para obtener el título de 
"Paisaje Cultural", teniendo como su principal enfoque el respaldo histórico y simbólico de los edificios de estas ciudades en el contexto de la cultura y la identidad de esa región.

PALABRAS CLAVE: Narrativa espacial regional; paisaje cultural; patrimonio construido; ciudades de puerto histórico; Recôncavo Baiano

\section{INTRODUCTION}

It has been noticed in the last decades that the approaches and debates on the heritage urban dimension is expanded, both in the academic, as the different political and administrative levels of government, especially with regard to the preservation policies at the global, national, regional and local levels. It is also noticed the growing number of research on this topic in Architecture, Urban Geography and History.

The main direction of the research that turned out in this article comprises the urban morphology of the cultural landscape of the historic centers in seven port cities of the RecôncavoBaiano (Jaguaripe Cachoeira, São Francisco do Conde, Maragogipe, Santo Amaro, Nazare and St. Felix) delimited by the ArtHeritage and Cultural Institute of Bahia - IPAC, in the late1970. The focus is the heritage built over the historical process of production and spatial organization of them, with the time frame the 19th century.

As research procedures, we use the bibliographic and documentary research; the use of iconography with the reproduction of plans of the historic centers of the mentioned cities, besides photographs of the period and current ones coming from the fieldwork.

The text is divided into three topics, besides this introduction and the final considerations. The first one deals with the main concepts that guided the research: landscape and heritage. We treat such concepts as structuring, which subsidize what we call mediator concepts inherent to them, such as cultural landscape and cultural heritage (material / built). That relation between structural concepts and mediators was indispensable for the understanding of what we denominate the simultaneous production of territories, from which you can get a similar regional spatial narrative.

The second topic deals with the cities in the historical context of the formation of regional urban network. The third topic we make a description, analysis and interpretation of IPAC's inventory, above, based on the plans of the historic centers of the cities mentioned. In the final considerations we made some comments and recommendations which we found relevant. 


\section{LANDSCAPE, HERITAGE AND IDENTITY}

Aassuming that, according to which the set of socioeconomic , cultural and political events produced throughout history resulted in similar landscapes in the territories of the cities, mainly in the historic centers of each one of them, where the built heritage is the most visible cultural expression, reflecting the socio-spatial content that made part of them in earlier times.Therefore, the reading and interpretation of these urban landscapes made of materiality produced in those territories, may reveal one or more space and common narratives to them. That is, a regional spatial narrative, detected in the simultaneous production of territorial spaces through the temporal concomitance and similarity of the cultural landscape in the production of the urban space. All of them strengthen the sense of regional identity of that urban network.

According to Oseki; Pellegrino (2004), the landscapes are imagined representations invented in the $4^{\text {th }}$. century, in China. Later, the word and the corresponding notion appeared in Europe in the Renaissance incorporating in the Latin languages the suffix (agem) (act=action on) the word (País )(country), which meant canton( district), region or province.In this perspective, we can infer that landscape is a process and can be constantly changing in form or content. An example is the old towns which were reinvented in their historical evolution process, making its landscape heritage and reusing them for different functions from the ones they originated.Therefore landscape is form, content, structure as well ... It is a continuous and discontinuous action throughout the production process and spatial organization of places and regions, set throughout history and according to the native culture and alien influences in it.

Here we draw attention to the intersection between two scalar dimensions of observation and investigation of great interest in the landscape and heritage concepts, especially with regard to urban planning process and the preservation of the built heritage. The first of them concerns a wider scale (regional), panoramic, the set of urban and cultural landscape of the cities, towards the urban sets. The second concerns the content of this landscape in a less comprehensive scale (local), but not least, that is the heritage in the form of its monuments, even in isolation.

The derivation of the concept of landscape as "cultural landscape", for example, complements the city's analysis in view of its cultural heritage / built.

The understanding of "cultural landscape" is conceived as one of the mediator concepts of our analysis, arising from a broader concept: the concept of landscape. The latest one, in turn, works as a structural concept and a dominant and articulator category between the description and analysis of the research object. Therefore, the concepts here cited work as analytical categories as well.

Eletronic Magazine: Time - Techinique - Territorry, V.6, N.2 (2015), 1:24 ISSN: 2177-4366 
The use of the category "Landscape" works as an articulator of theoretical / empirical relation, because we regard the landscape is where the results of the connection processes between society and space within the object of research, conceived as a form object, which reveals past social content.

We are considering that the landscape is the matrix of a spatial narrative that is interactive on the local and regional point of view. In the case of our research object, local and regional scales align an entire analysis dimension since the formation of urban apparel to the consolidation of regional urban network.Both in terms of its peculiarities, similarities of form and content, and in temporal concomitance and complementarity in their functions.

We agree that Almeida (2013), who considers the cultural landscape can contemplate symbols, meanings and become heritage, and come to be institutional. For this author, analyzing the meaning of landscape in the Brazilian Constitution of 1988, which deals with t Brazilian cultural heritage in Article 216, and in item V, which are defined "urban sets and sites of historical, natural, artistic, archaeological values", asserting that:

[...] The landscape is perceived as one of the central elements in the culture; an ordered set of objects that can be interpreted, we repeat, as a text that works as a creator of signs by which a social system is transmitted, reproduced, experienced and explored (ALMEIDA, 2013, p. 189).

For us it is evident in the above assertion that the concepts of culture, landscape and heritage are closely intertwined and almost fuse, when the perspective of a review in Historical Geography, of the urban landscape, focusing on materiality built in the territory. Even for the same author cited above,

The heritage and the territory thus have the both roles of interpersonal mediators and cements identity in society. The material components such as buildings, vegetation, properties, for example, and intangible assets as images, culture, symbols, etc.They are asset values (ALMEIDA, 2013, p. 190).

For Almeida (2013, p. 188), "[...] the fact that the cultural landscape be a way to demonstrate the territorial identity shows another perspective of how to 'read' the landscape." In this sense we understand that reading the "land used" can be made through the mediation of concrete image installed in it. 
The concept of cultural landscape has been an important tool in the recognition of the historical value processes, given in Rio de Janeiro in 2012. But the Institute of Historical and Artistic Heritage (IPHAN), even when inventorying intangible heritage, will choose their territory, that is, in space that concretizes the idea of historical recognition value. And, according to Paes (2010) geography, which deals with these spatial concepts, can not be out of the process.

It can be seen in the above assertion that the concept of landscape refers to the study of the territory from the perspective of preservation policies, which in turn are included in urban and regional planning policies. In other words, space, territory, heritage, identity, landscape and culture complement each other in the analysis process.

As the concept of cultural heritage, there are many categories and conceptual developments arising from the same, especially in the analysis from the perspective of Historical Urban Geography. Among these included: historical, artistic and architectural heritage, urban heritage, environmental heritage, tangible and intangible heritage, archaeological heritage, vernacular heritage, built heritage etc .. At this point we agree with Scarlato; Costa (2013, p. 371), when they insist on the need to make clear which the theoretical principles should be associated with the term "heritage" in a survey of geographic bias.

For us, "heritage" can not be apart from culture and landscape, for example, when analyzing the historical materiality of the urban and the city in direct connection in the formation of regional territories. So we agreed that this discussion in Geography, according to Scarlato; Costa (2013, p. 371). "[...] Seems to be basted to the spatial inheritance idea when the set of tangible or intangible property synthesizes a legacy in the dialectics of the historical process that expresses in landscapes and in their own territory $[\ldots] "$

The analysis of the built heritage of port historic cities in the Recôncavo Baiano leads us to have a notion of the city as a cultural product. In our case, cities that express a similar material language at a particular time. Therefore, we focus our analysis of the heritage on its deployment material, built, without ignoring that it is part of a more comprehensive concept of urban heritage that is in continuous process of materialization and reframing.

\section{URBAN NETWORK AND REGIONAL IDENTITY}

The histories of the seven port cities in the Recôncavo Baiano are confused with the history of that region, and Brazil's. They belonged to the first and second generation in the formation process of a Luso-Brazilian urban civilization, usually associated with a geographical area, produced and organized under the economic, social and cultural rights influence and their respective 
ancillary activities. As well as they suffered influences of a material culture and even other civilization assimilation in the technical sense, especially in urban structure and shape.

Andrade (2013, p. 242) after a study that examined abundant cartographic documentation of the $18^{\text {th }}$. century, as well as ecclesiastical documents of the same time, concluded that in that century was formed an incipient regional urban network, with centrality in Cachoeira and articulations with other urban formations in the Reconcavo Baiano. And that the referred network "[...] connected the Reconcavo Baiano villages of All Saints Bay and Salvador city from a fluviomarítima loop and road (internal roads)."

Said author also points out that this network stood out "[...] the urban formations that were located at the endpoints of fluvial navigation of the abundant rivers of the region, among them Cachoeira village in the last navigable stretch of Paraguaçú river" (2013, p. 242). The latest one keeps to this day an important role in the regional scenario, due to its cultural manifestations of African origin, as well as its imposing architectural and urban set of the $19^{\text {th }}$. century still preserved.

On the map below, Figure 1 below, we can have an idea of the formation beginning of the cities network in the Reconcavo Baiano, from the streams and the most dynamic routes in the region.

Figure 1 - Hierarchical ways of Urban Reconcavo Baiano Network at the end of the $18^{\text {th }}$.century

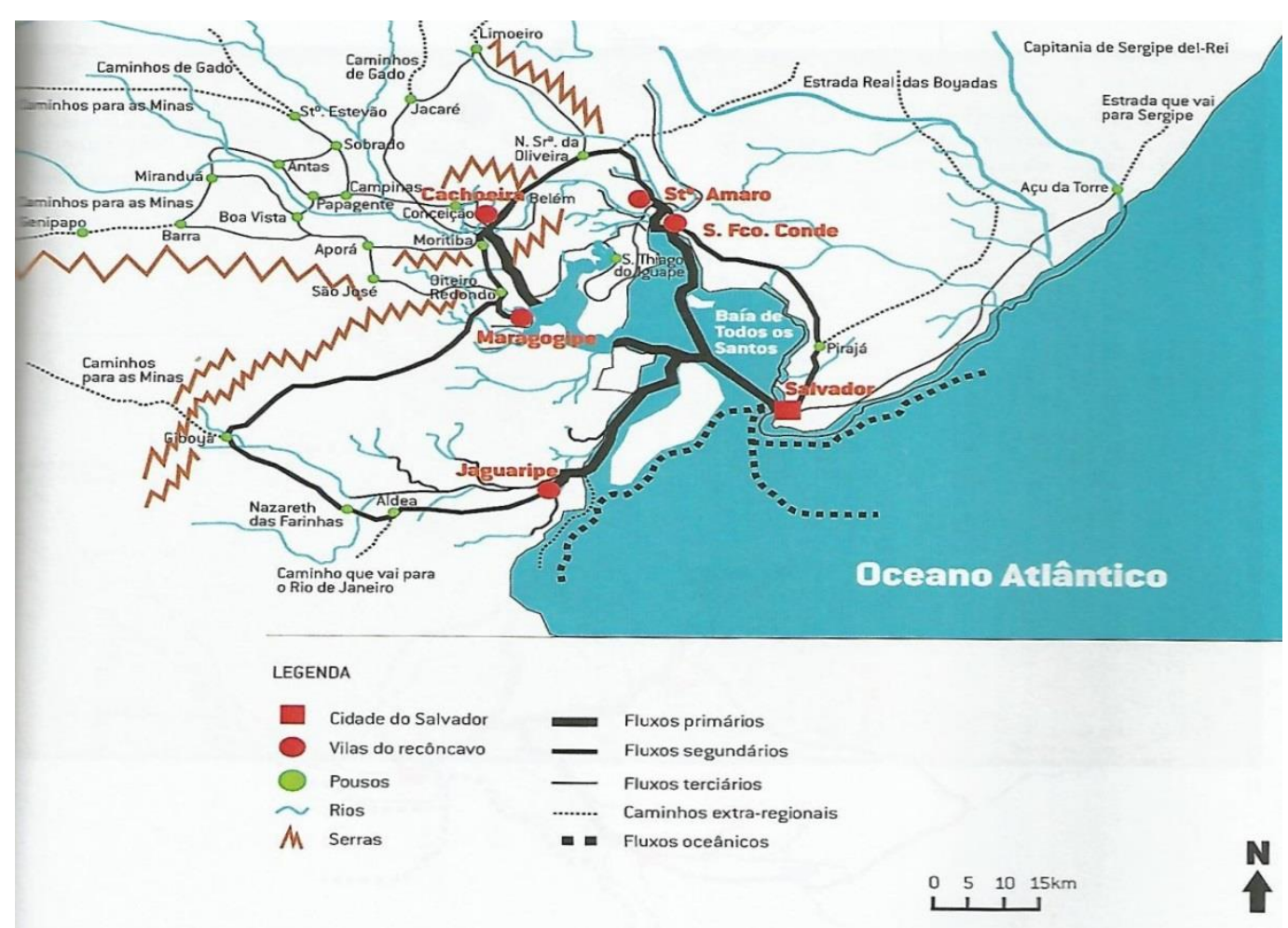

Source: (ANDRADE, 2013, p 249). 
The other abovementioned urban formations used to be port towns of Jaguaripe, São Francisco do Conde, Maragogipe and Santo Amaro. Later in the $19^{\text {th }}$.century, two more villages stood out in that regional scenario. Nazare and St.Felix villages.

The abovementioned study reveals the articulation that these towns maintained since the end of $18^{\text {th }}$.century This process had continued more and more fluidly through the implanted infrastructure in the territory at later periods, resulting in an increasingly fast and intense connection, especially from the second half of the $19^{\text {th }}$. century. As we previously reported, said Cachoeira village was important as political leadership during the battle of independence, becoming Headquarters of the Governing Board and later the Provisional Government (BAHIA, 1982).

Among other arguments used by Andrade (2013, p. 84) to justify the statement above and that meets our research perspective, we emphasize the reference to the concentration of the largest regional built sets in those villages and cities, especially the "religious buildings, civil and public which demarcated one sumptuousness only found together in the city. " That is, the image of opulence, density and monumentality in the urban texture of cities in screen, which suggests a cultural identity in their urban landscapes.

Considering what was said before, we seek a panoramic view, analyze by analyzing the plans of historic centers enclosed by IPAC's inventory (BAHIA, 1982) find the similarity and temporal concurrence of buildings and architectural styles built in that period.. Below is a brief description of each of these cities, based on the previously mentioned inventory.

\section{CONTEXTUALIZATION OF THE CITIES AND PRODUCTION OF HERITAGE}

At this topic was analyzed in a multiscale approach (regional and local), the historical context, the spatial network production and the relationship among the cities studied. We also tried to analyze, through the number of registered buildings in the plans of the historic centers enclosed by IPAC's inventory, find temporal concurrence and similarity of forms and architectural styles among them in the studied period. That's what we will see next.

We will start by the City of Jaguaripe, figure 2 below, which, along with Cachoeira and São Francisco do Conde, they were emancipated as village condition in the late $17^{\text {th }}$.century. 
Figure 2 - view of the city of Jaguaripe from the river of the same name

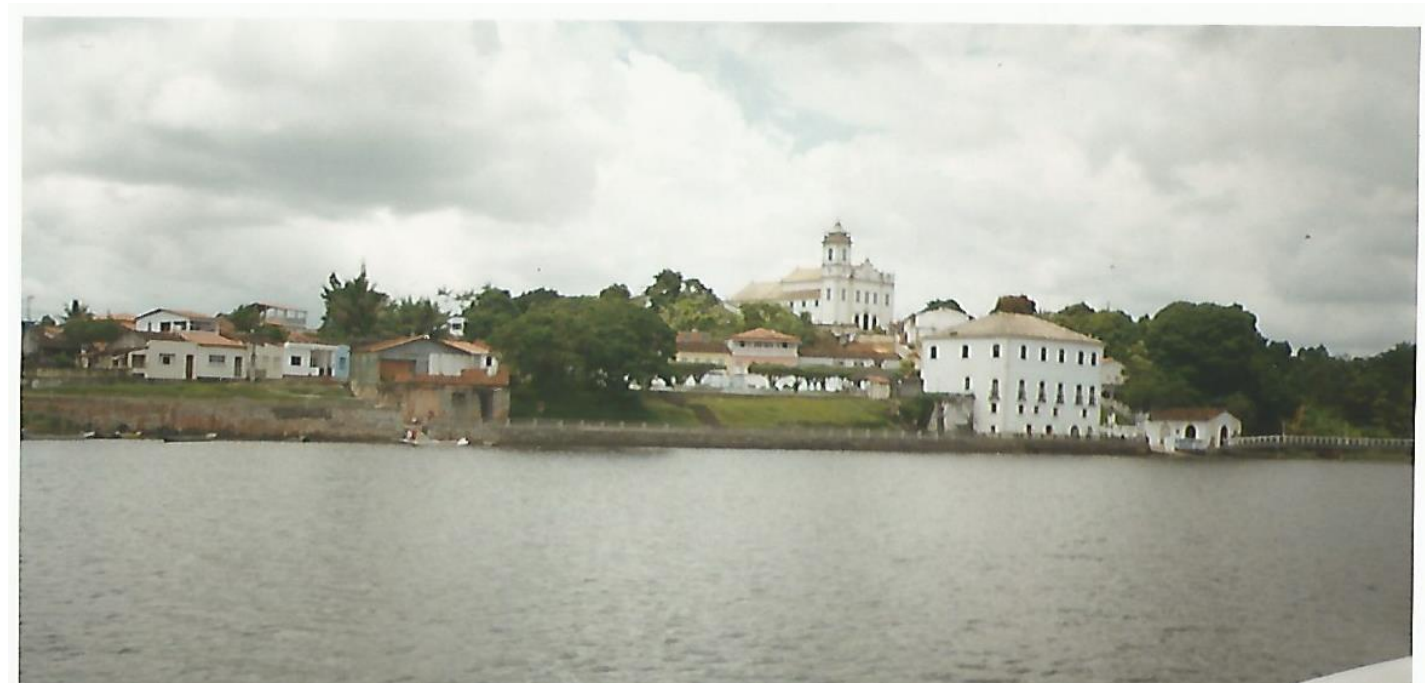

Source: Author's Image, the first decade of the 2000s

IPAC describes the historic center plan of Jaguaripe, Figure 3 below, where its architectural heritage consisted of 112 properties, of which only five were considered as "relevant architectural interest," originated in $17^{\text {th }}$. and $18^{\text {th }}$.centuries.Almost entirely consisted of single-store houses (BAHIA, 1982).

Figure 3 - Plan of the historic center of Jaguaripe city - BA

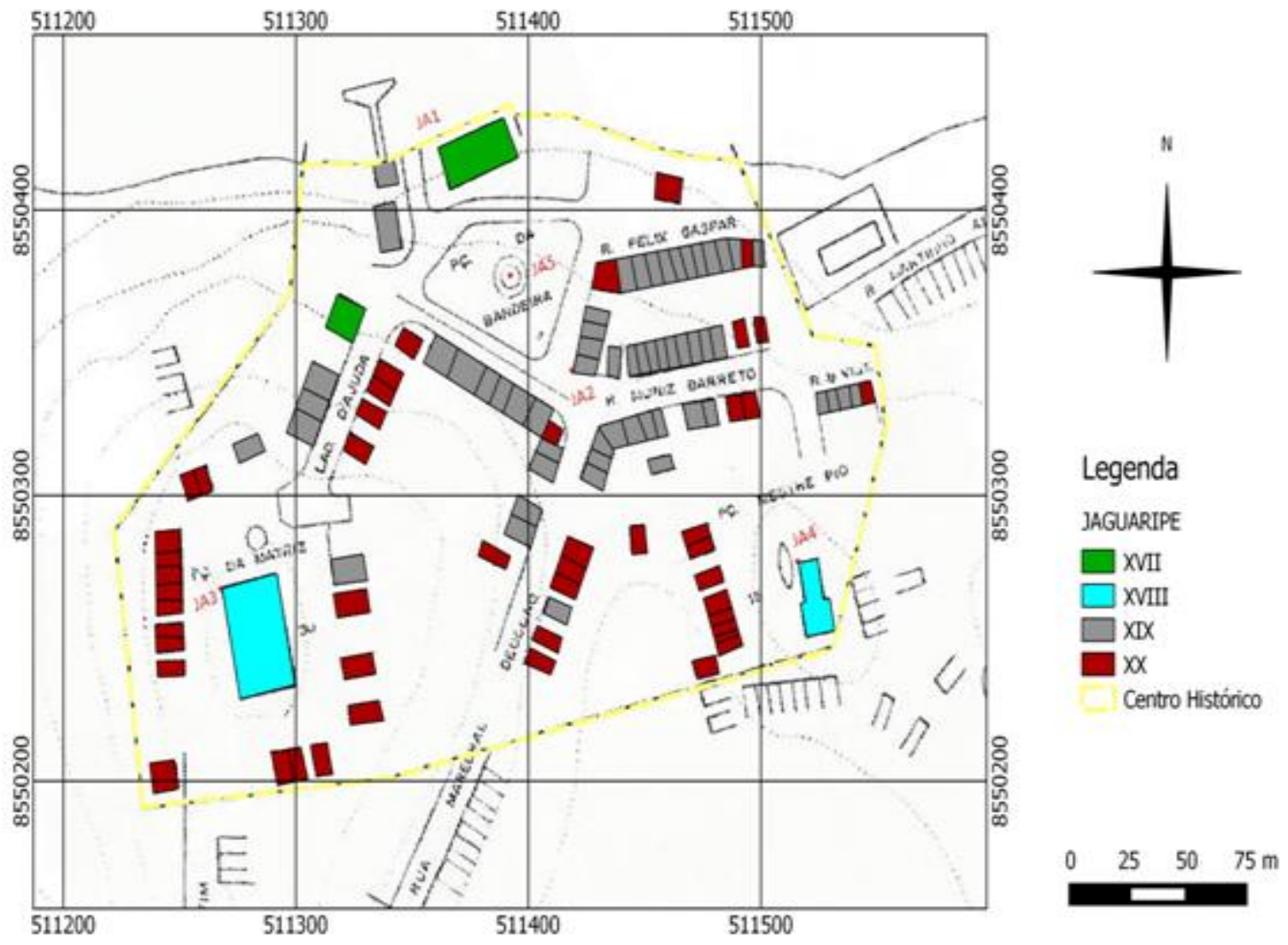

Source: basemap IPAC, BAHIA, 1982, modified by author and geographer Marcus Fabius (UNB) 
The city of Jaguaripe, despite being main home to one of the largest cities in the state nowadays, did not follow the development of the other cities. This is due to its geographical location and structural changes related to the evolution of the means of transport, benefiting other places like Nazare, located in a strategic place in the last navigable stretch of Jaguaripe river, in connection with the railway network of the time, from the second half of the $19^{\text {th }}$.century.

Unlike Jaguaripe city, Cachoeira Figure 4, below, also promoted to the village condition at the end of the last decade of the $17^{\text {th }}$.century, prospered and developed on the left bank of the Paraguaçu river, on a river terrace between the pier and the slope of Valley. Its urban area is more spacious than the city of San Felix, on the opposite bank of the river.

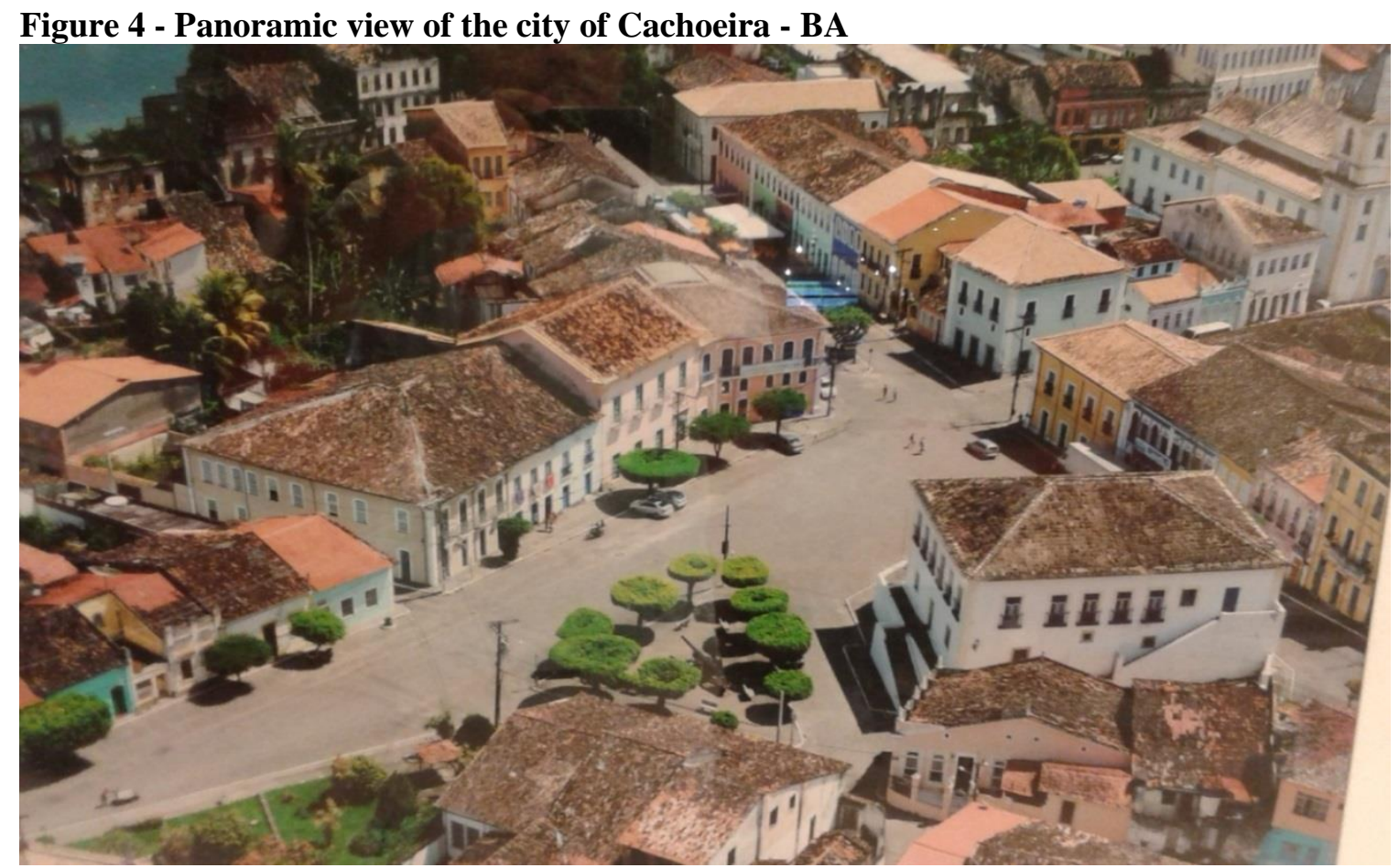

\begin{abstract}
Source: Photo of the Photo on display: "He who loves Bahia", Salvador and the Reconcavo Baiano: through the lens of photographer Osmar Gama. Shopping Barra. Salvador - BA, 2015.
\end{abstract}

According to Spix; Martius (1916, p. 35), in the early $19^{\text {th }}$.century, Cachoeira was "[...] undoubtedly the richest, most populous and one of the nicest towns in Brazil. Numerous grocery stores and warehouses full of various European articles reveal the high degree of movement of their trade ". Sugar production was from the beginning of its origin in the $16^{\text {th }}$.century until the early $19^{\text {th }}$. century, the predominant activity. Originated from a sugar mill, this town prospered and the mills had increased over this period in the city. However, trading activity also played an important role in the development of the village. Its privileged situation between two complementary economic regions, the Reconcavo and the Dry backland, besides it is in the navigable limit of the Paraguaçu 
river. They were two important factors that stood out in the context of the region, while Brazil Colony, Empire and Republic (BAHIA, 1982).

In the case of Cachoeira city, despite the safeguard projects of its assets, implemented at the federal and state level, many of its buildings were still in a precarious conditions, from the time of IPAC's inventory, and characterized the defined area of its historic center: the GP-1 zone (degree of protection-1), defined in the plan, has an area of 20.13 ha, where there are included 29 streets, 8 squares and 668 properties. From these, 35 were inventoried and had their typologies characterized according to the above categories mentioned. As for the state of conservation of buildings $86 \%$ were in poor condition; 9\% satisfactory and 5\% bad (BAHIA, 1982, p. 30). Figure 5 below.

Figure 5 - Plan of the historic center of Cachoeira - BA

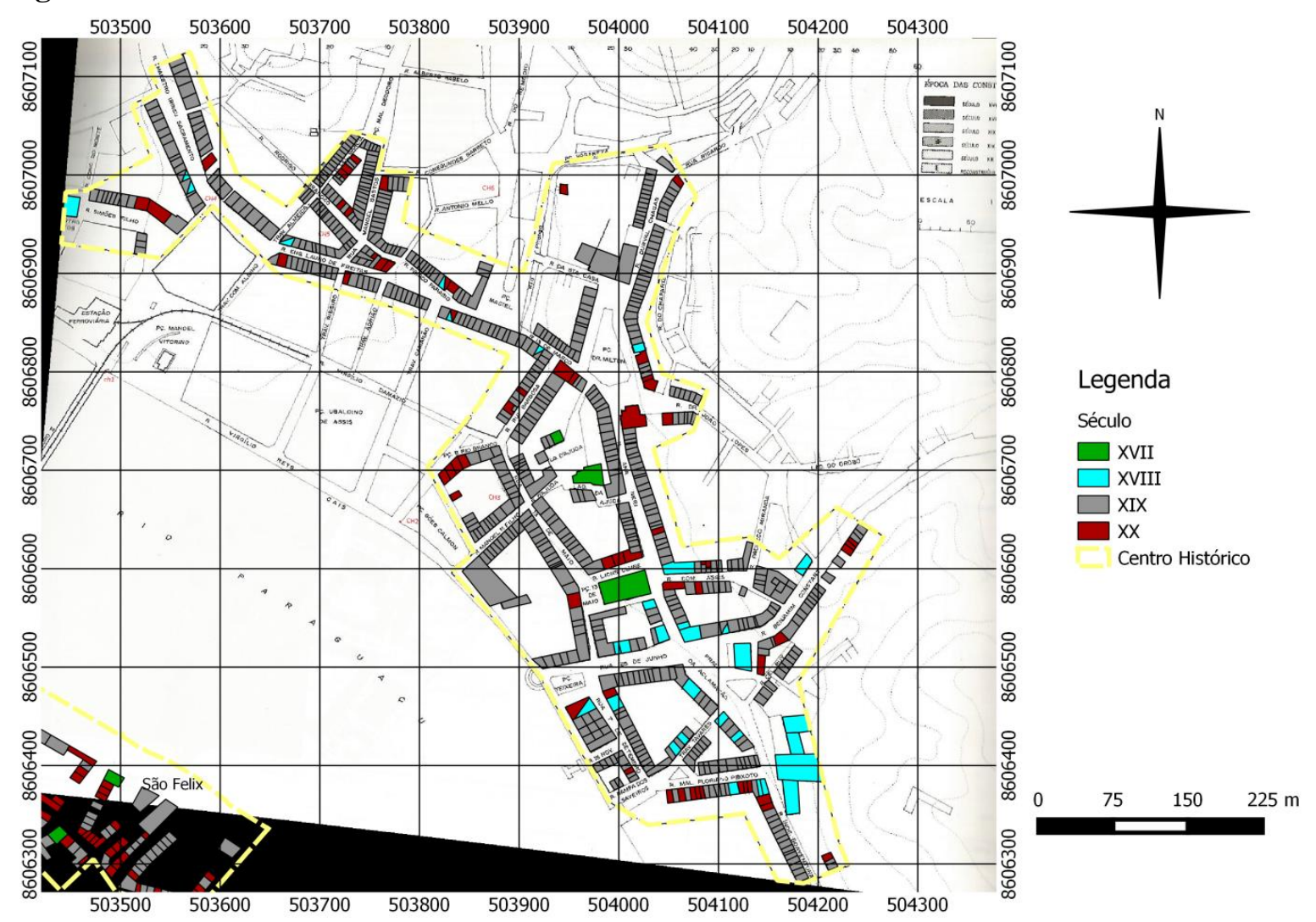

Source: basemap of IPAC, BAHIA, 1982, modified by author and geographer Marcus Fabius (UNB)

The description of IPAC's inventory, as the situation in the historical center of São Francisco do Conde city and the analysis of its respective plan shows its urban layout is primitive, originated in the $17^{\text {th }}$.century and its houses consist of half-wall story houses, mostly in the $19^{\text {th }}$. and $20^{\text {th }}$. centuries (BAHIA, 1982, p. 162). Figure 6 below. 
Figure 6 - Historic Center street - São Francisco do Conde city - BA

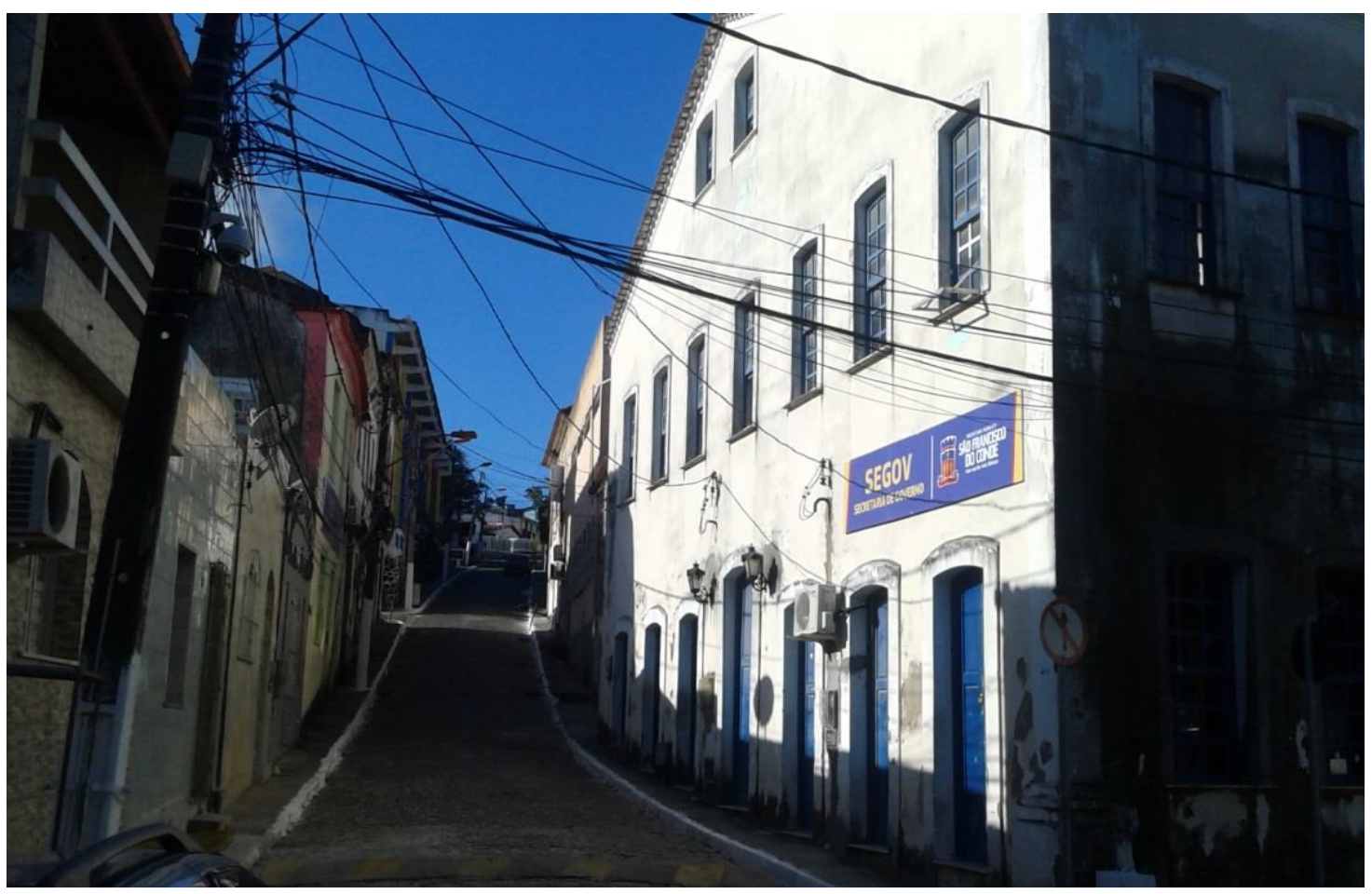

Source: photo of the author in the work field, in 2015.

So this way is described the historic center of this important port city in the Reconcavo Baiano by the abovementioned inventory:

The residents of S. Francisco do Conde, born around the convent, spread down the slopes of the promontory to the small harbor. Itis typology is simple, that is, mononuclear and fairly homogeneous, as "Urbis formae". Its site is rugged and its twist of irregular streets. The city's "social environment" consists of the waters of All Saints Bay, that surround on three sides, and green hills on the northern square. This combination of privileged natural site with the exceptional work of man is the greatest interest of all. Its historic center, which is defined in the attached plan, measures 13.57 ha and was rated degree of protection two (GP-2) due to numerous replacement of houses. Its urban layout is primitive, originating in the $17^{\text {th }}$. century. In this area are included: 15 streets, 4 squares, the fields of the Franciscan convent, river bordering the city and 134 buildings [...] The most important public space is the Arthur Salles Square, where also the most significant monument set is located: the Convent of St. Anthony. It stands out even among the relevant buildings, the parish of St. Gonçalo, the Chamber House and Jail and three buildings of civil architecture, inventoried below. Its houses consists of half-wall single-store houses, most of the $19^{\text {th }}$. and $20^{\text {th }}$. centuries (IPAC, BAHIA, 1982, p. 162). 
In Figure 7, below, we can see the distribution of the plan from the historic center of that city above mentioned .

Figure 7 - Planof the historic center of São Francisco do Conde city - BA

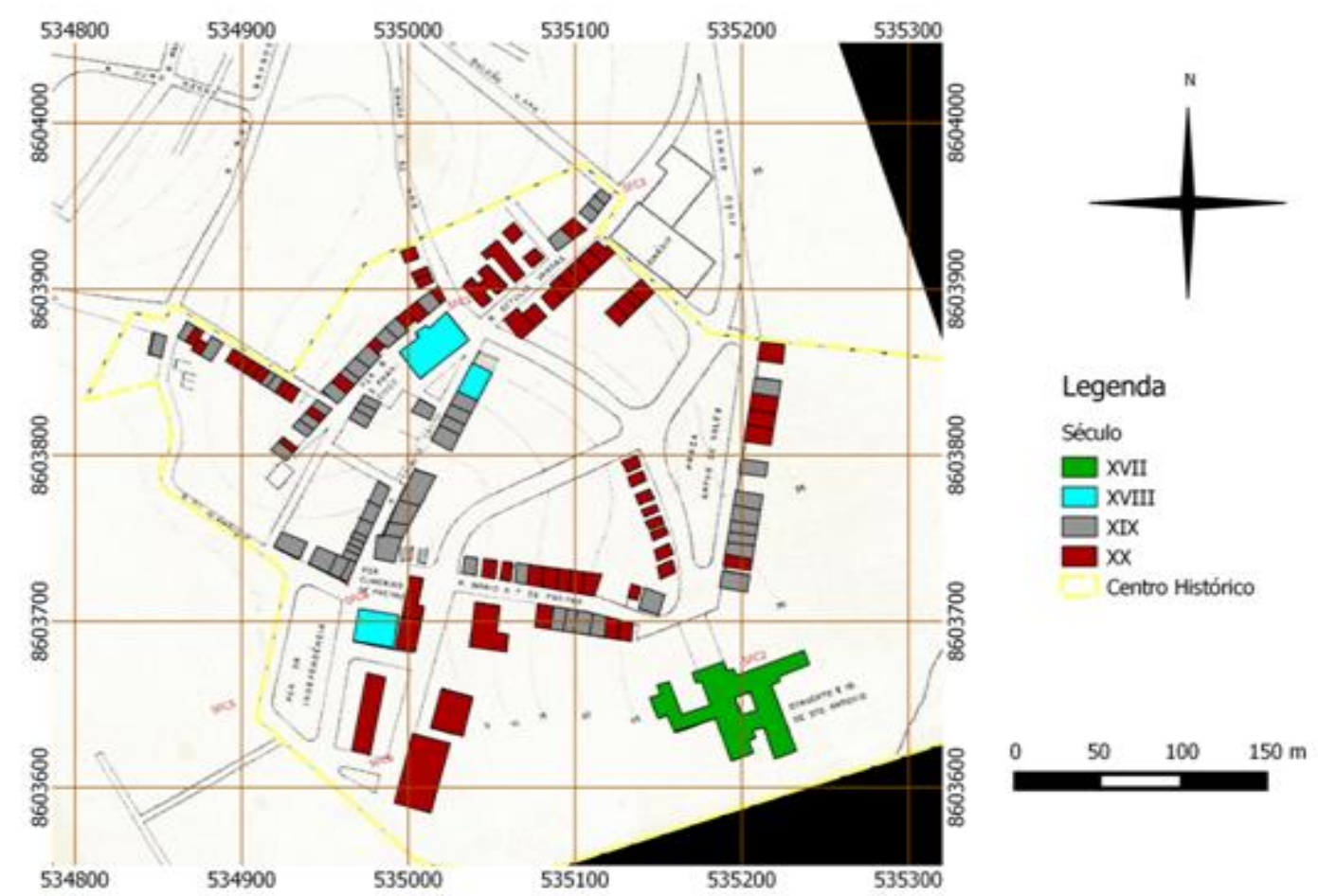

Source: basemap IPAC, BAHIA, 1982, modified by author and geographer Marcus Fabius (UNB)

The presence of Petrobras in the second half of the $20^{\text {th }}$. century, in San Francisco do Conde city, and the reflection in the GDP of the municipality, did not reflected, in fact, a greater safeguard condition of their houses coming from the $19^{\text {th }}$. century. We noticed in the IPAC's inventory and field research, that the referred city is the one that least conserved erected goods in time frame of research and today.

In the case of Maragogipe city, it is surrounded by mangroves and two navigable rivers, the Paraguaçu and Guai, and other smaller rivers that bathe their land, which contributed during the $19^{\text {th }}$ century for its expansion and development, as a result the importance of tobacco growing in the Bahia's economy. Maragogipe developed as a port to support sea-river route that end in Cachoeira city. Similar role played by Jaguaripe in relation to Nazare. Defensive reasons over the first two centuries of colonization made this site mentioned above be chosen, foundation of the city, as well as other researched core and described ones above (BAHIA, 1982). Figure 8.below. 
Figure 8 - View of the city of Maragogipe in the 1970s, especially Church and Town Hall and jail and its port

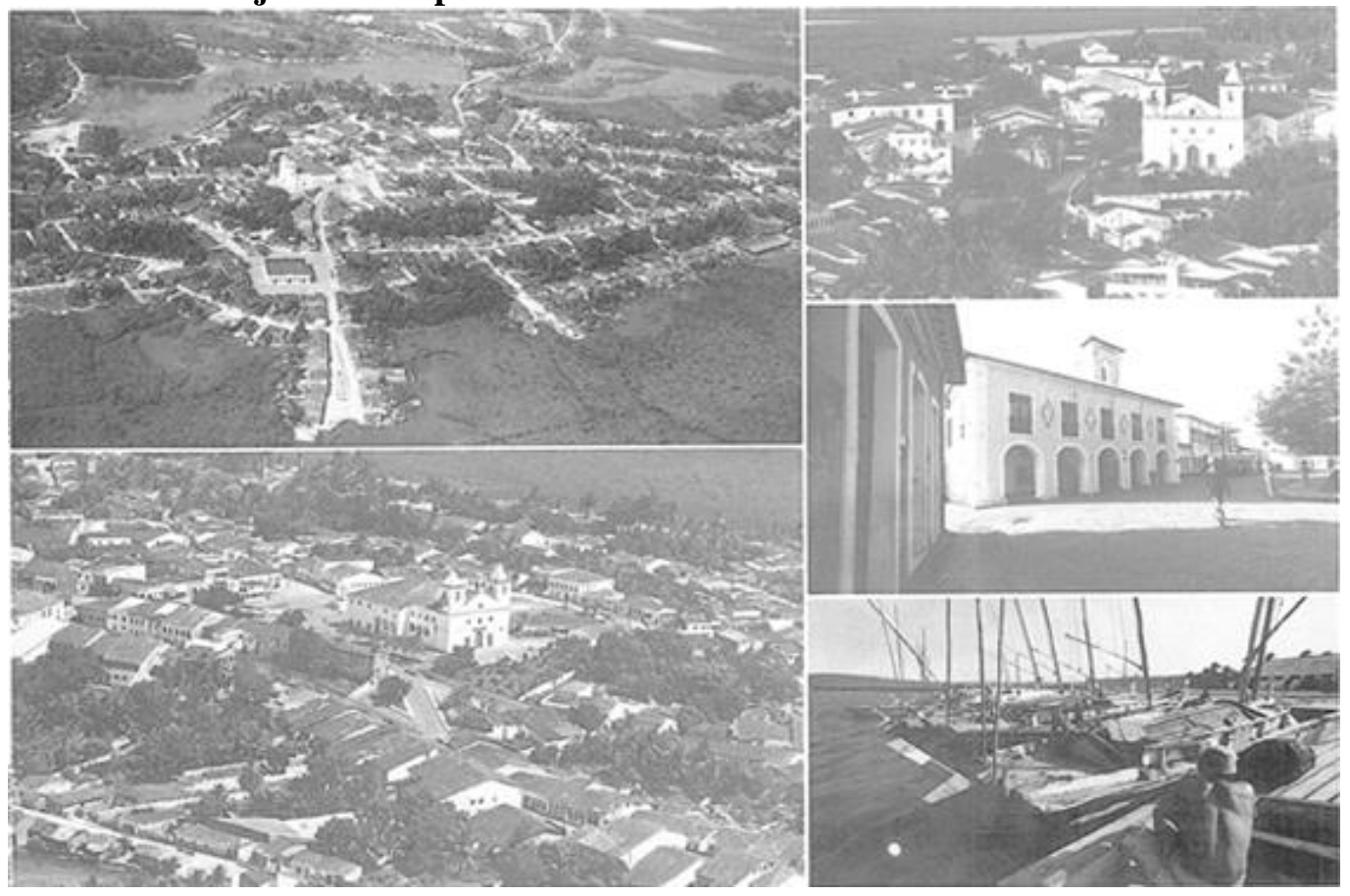

Source: IPAC's inventory. BAHIA, 1982, p. 189

As in other cities, most homes in Maragogipe was erected in the $19^{\text {th }}$.century, except those of institutional and ecclesiastical architecture, such as the parish church and the Town Hall and Jail, built between the $17^{\text {th }}$.and $18^{\text {th }}$.centuries.

Spix; Martius (1916, p.38) on a trip towards a mill on the banks of the Paraguaçu river, in the first half of the $19^{\text {th }}$.century, described the Maragogipe village as a "rich town situated at the bottom of this bay", that "[... ] contributes significantly to the strong trade with the capital, existing in its fertile surroundings many sugar mills. "

Among the best infrastructure improvements implemented in the municipality, is the opening of the carriageway road linking its head office to the city of San Felix in 1807; the creation of chairs of first letters and Latin; regular line establishment steamship to Salvador in 1839; and the installation of cigar factories still in the same century (BAHIA, 1982).

Regarding the description plan of the historical center of Maragogipe, the inventory reports that "[...] The Parish of São Bartolomeu, located at the top of the hill, emerges as a major highlight of the houses of the historic center, consisting of houses and originating houses $19^{\text {th }}$.century. Noteworthy are also the Town Hall and Jail and some houses, [...] "(BAHIA, 1982, p. 188). Figure 9 below. 
Figure9 - Planof the historic center of Maragogipe city - BA

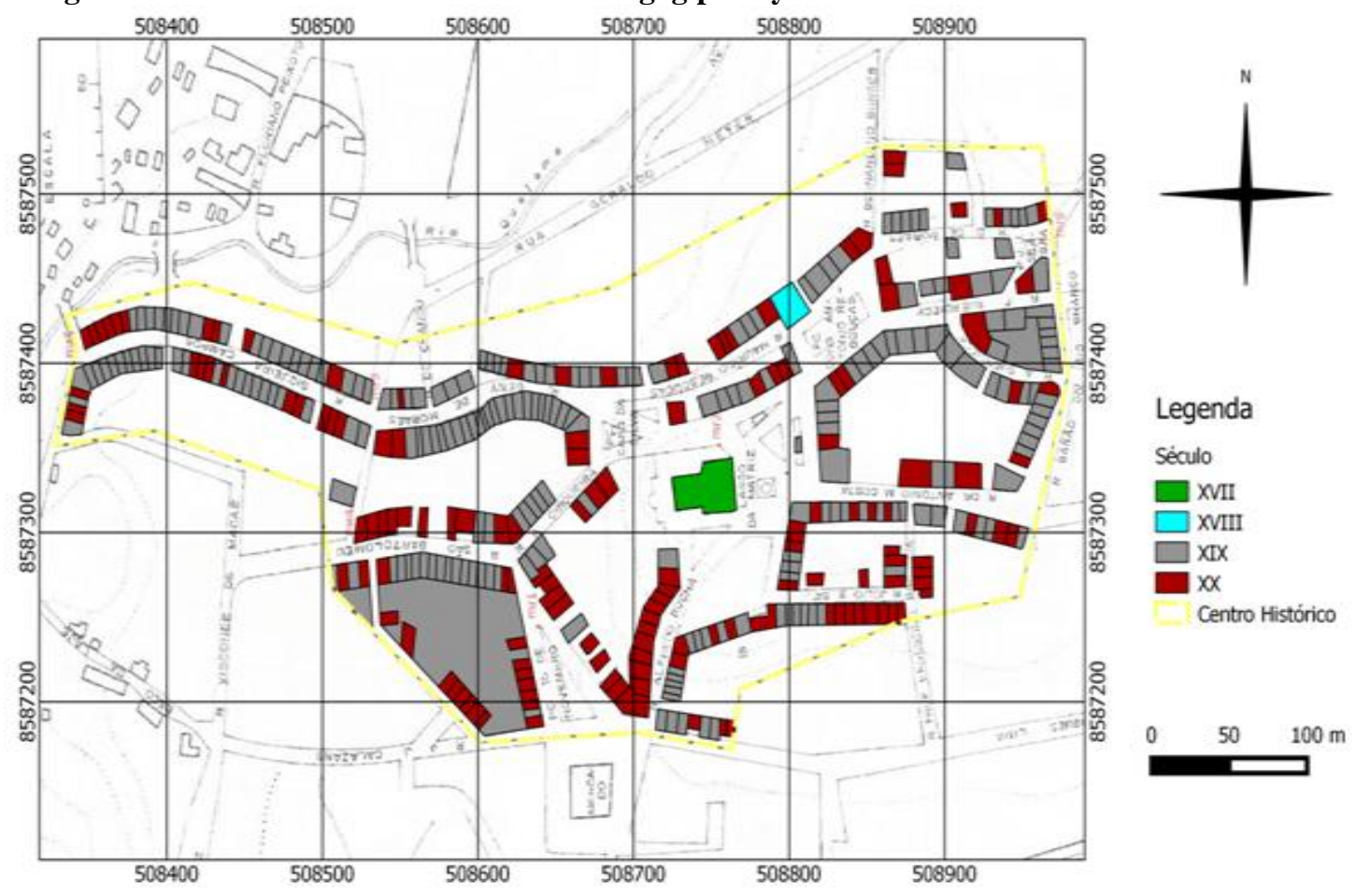

Source: basemap of IPAC, BAHIA, 1982, modified by author and geographer Marcus Fabius (UNB)

As for Santo Amaro, according to Tavares (2008), the village of " Nossa Senhora da Purificação" was created in 1724 by Vasco Fernandes Cesar de Menezes, General Governor. The municipality of Santo Amaro was established in 1727 and the village was emancipated to town status in 1837. Its territory was emancipated from São Francisco do Conde. Its village dates from the second half of the $17^{\text {th }}$.century and has its origins in the homonymous Benedictine chapel (BAHIA, 1982).

The city is situated inside the Reconcavo, in the cretaceous sedimentation zone of the tectonic fossa that forms the All Saints Bay, expanding terraced of Subaé river whose navigation is done by small boats up to Santo Amaro . The city developed as a river port and regional trade warehouse (BAHIA, 1982)

The plan of the historic center of Santo Amaro, Figure 10, below, gives us a dimension of the extention of that area, showing a great moment in the $19^{\text {th }}$.century, due to the large number of historic houses and mansions registered in it. In the description of that plan, the IPAC's inventory, "[...] Its architectural ensemble is made up of houses and townhouses are the middle and late $19^{\text {th }}$. century. [...] The relevant buildings, numbering 12, are the middle of the eighteenth century and beginning of the next [...] "(BAHIA, 1982, p. 96). 
Figure10 - Historic Center of Santo Amaro city - BA
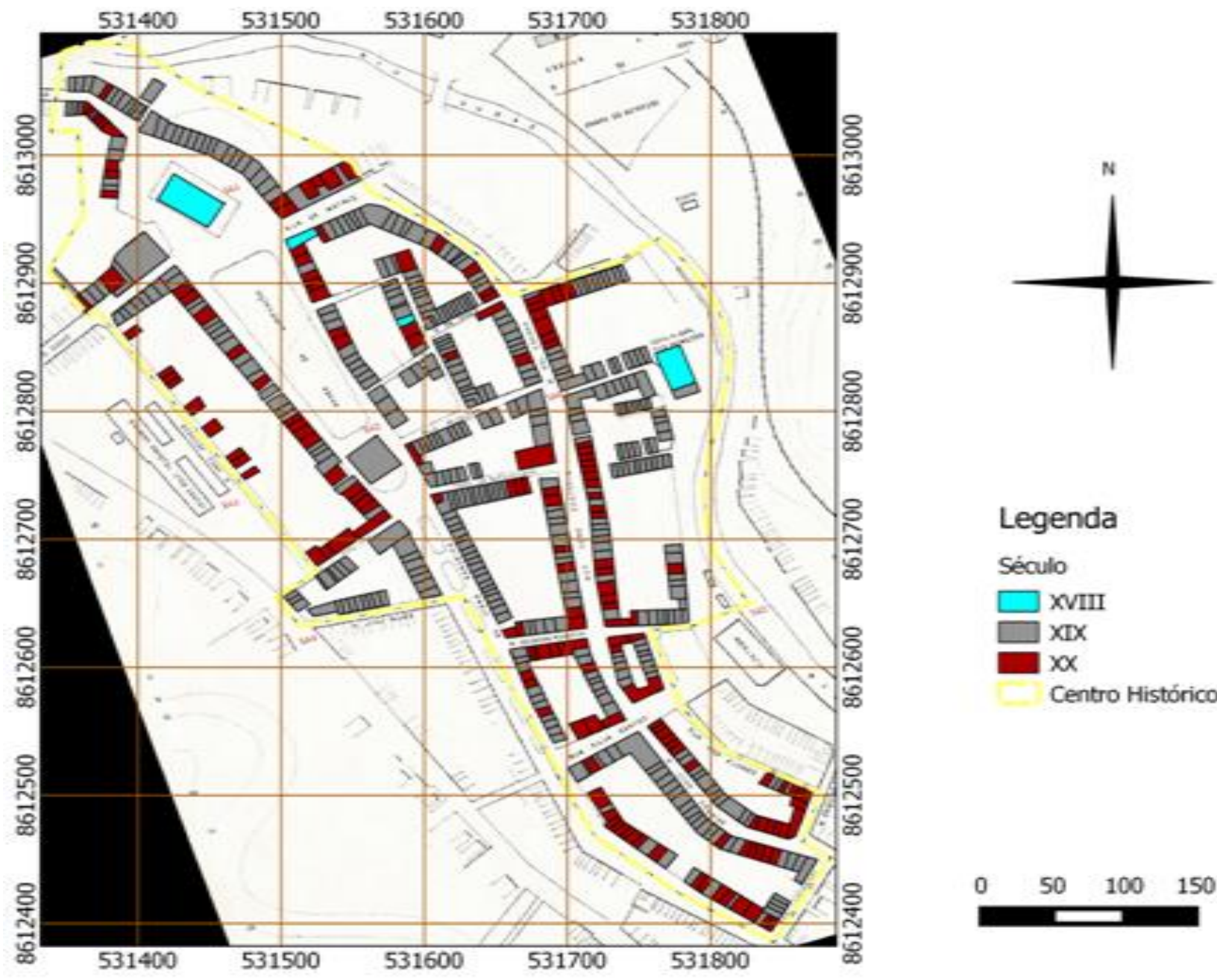

\section{Legenda}

Século

$\square$ XVIII

$\square \times \mathrm{XX}$

$\mathrm{x} \times$

Centro Histórico

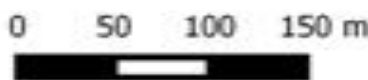

Source: basemap of IPAC, BAHIA, 1982, modified by author and geographer Marcus Fabius (UNB)

Once again we see references related to the buildings of the $19^{\text {th }}$.century, alluding to the intense dynamic of production of urban space and its urban set that century, as we can see in Figure 11 below.

Having a port located within the continent, in full zone of black clay soils, Santo Amaro snatched São Francisco do Conde's regional warehouse status and became the sugar port par excellence of the Reconcavo. Villhena (1969) noticed that in 1802, two roads ended in Santo Amaro. One in the north, that entered the backlands to the Maranhão, and other one to the south of Minas Gerais. The city also produced tobacco and cotton (BAHIA, 1982). 
Figure 11 - View and some streets of Santo Amaro city- BA, década de 1970

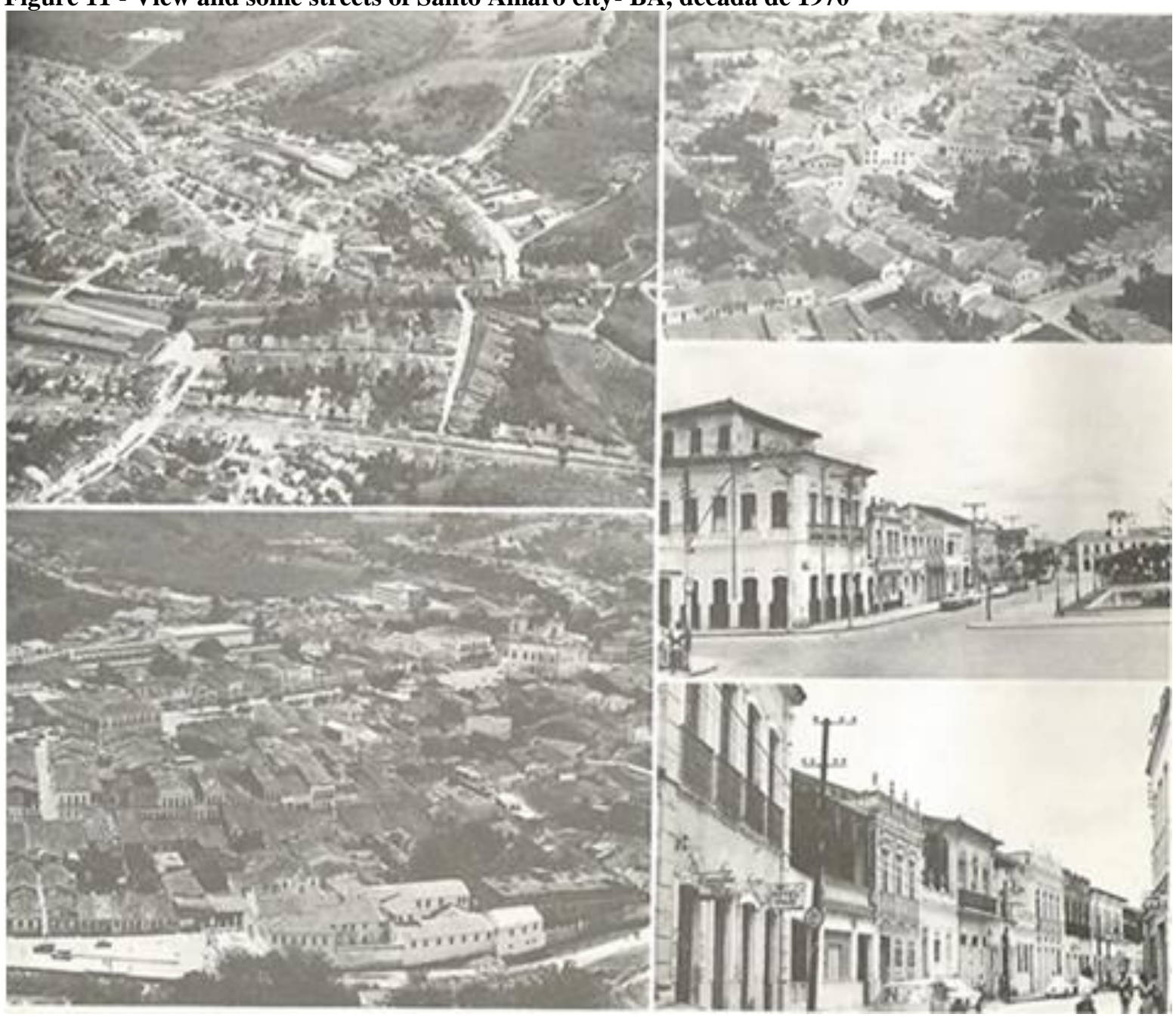

Source: IPAC's Inventory. BAHIA, 1982, p. 97)

Another city of fundamental importance to the region throughout the $19^{\text {th }}$.century was Nazare, which fits in the list of historical Reconcavo towns and had an important central role in inter- and intra-regional context in the territory of Bahia. A place where the density of the flow of goods and people through waterway and rail transport produced a built heritage that, over time, mark its urban landscape until nowadays.Figure12 below. 
Figure 12 - Panoramic view of Nazare city-BA, in the 1970s

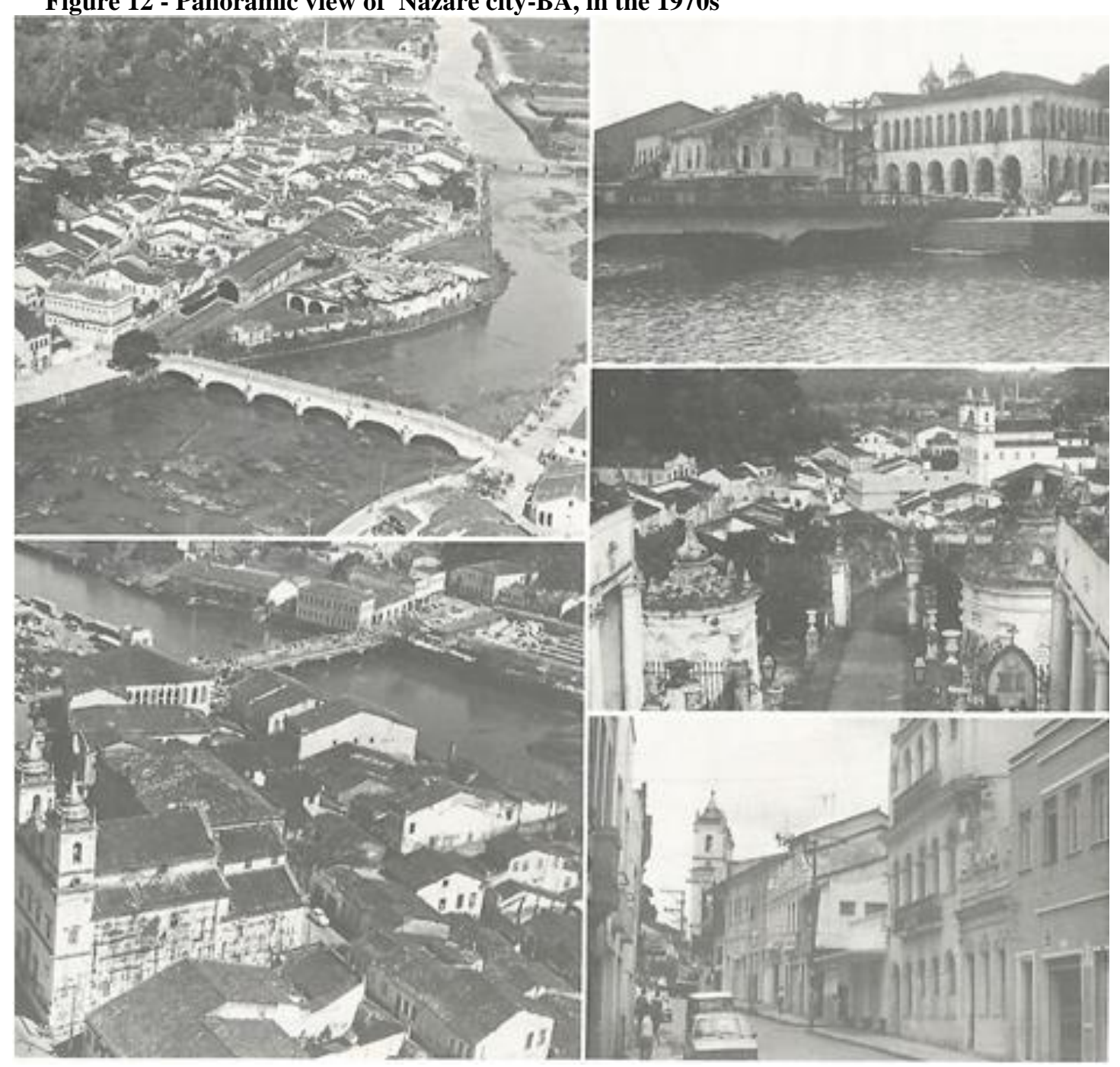

Source: IPAC's Inventory . BAHIA 1982.

According to the IPAC's inventory (1982) related to that city, the document (the historic center plan), Figure 13, below, called the GP-1, an enclosed area of 2.4 ha; were included seven streets and two squares. Yet according to a survey conducted in the research previously mentioned, its architectural heritage was fundamentally of the $19^{\text {th }}$.century. Of the 92 properties which comprised $18 \%$ were satisfactory conservation status; $64 \%$ in poor condition $18 \%$ bad. Among the monuments, the most important were the Church of Nossa Senhora de Nazare, the City Hall, as well as some houses inventoried at the time (BAHIA, 1982, p. 242). 
Figure13 - Plan of the historic center of Nazare city - BA

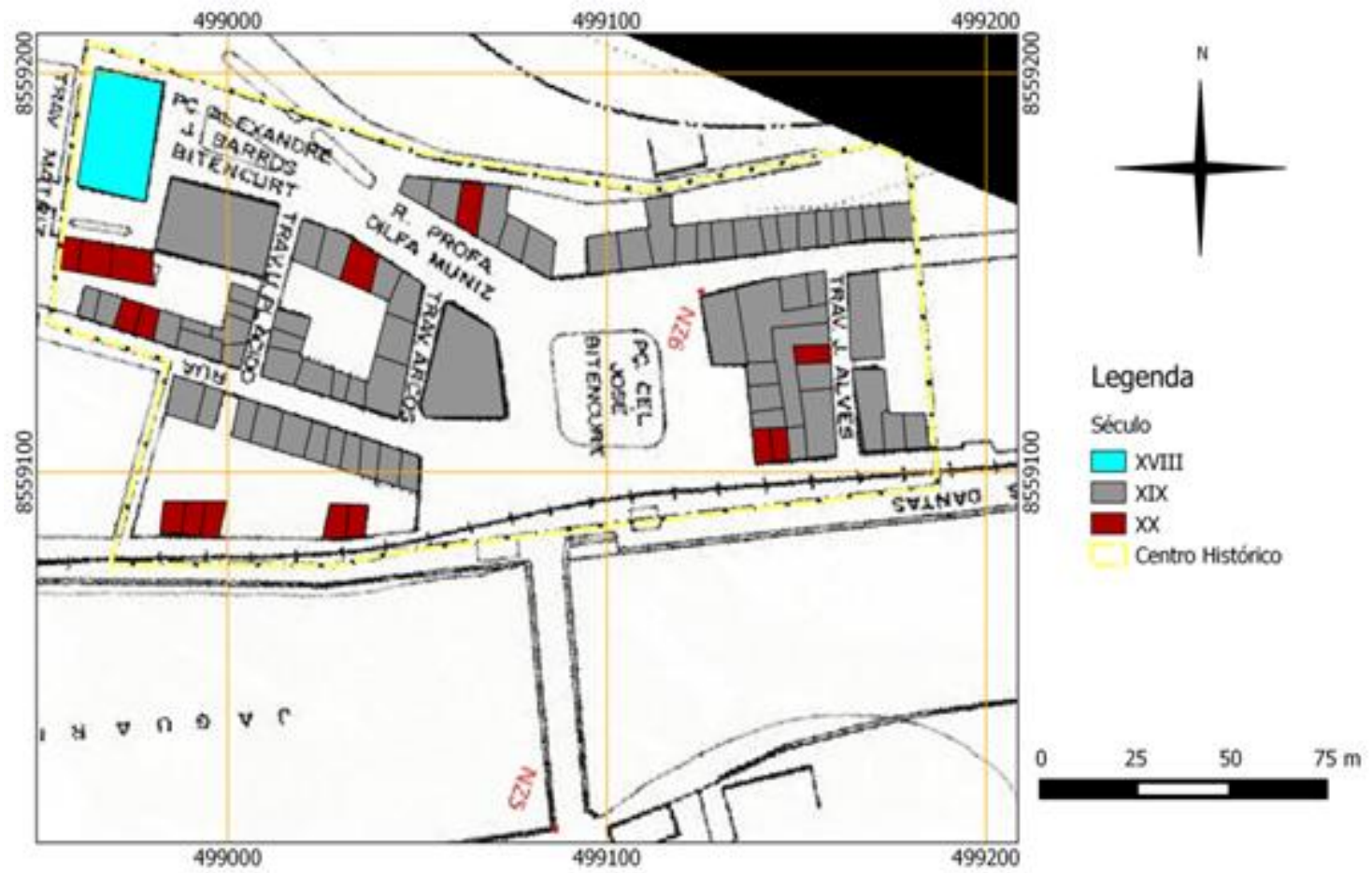

Source: basemap of IPAC, BAHIA, 1982, modified by author and geographer Marcus Fabius (UnB)

The city of São Felix developed due to the port of Cachoeira. Due to the nature of its land, which were more suitable for the planting of tobacco and food crops, especially cassava, It joined the so-called "Reconcavo Subsistence" (BAHIA, 1982, p. 329). In addition, its trading post function was very important as a drover terminal. However, with regard to the production of built environment it is much more modest than Cachoeira city, but greater than Jaguaripe. However, the setting up of most buildings also happened in the $19^{\text {th }}$.century.

About the characterization of plan of São Felix, Figure 14, below, represented in Figure 8, the IPAC's inventory says the following:

[...] São Felix is a city of simple typology, mononuclear, developed according to a nuclear matrix, parallel to the river. One end of this shaft extends toward Maragogipe; and the other toward the Stone Horse Dam, replacement of Bananeiras. The railway enters this axis, dividing the city into a narrow flat part, built on the river terrace, and another pending, with streets up the slope of the valley. Its historic center, rated the degree of protection (GP-1), has an area of four ha. Within this zone are comprised a square, eleven streets and part of the right bank of the Paraguaçu. 101 properties located there are in almost all of the $19^{\text {th }}$. century [...] (BAHIA, 1982, p. 330). 
Figure14 - Plan of the historic center of San Felix city - BA

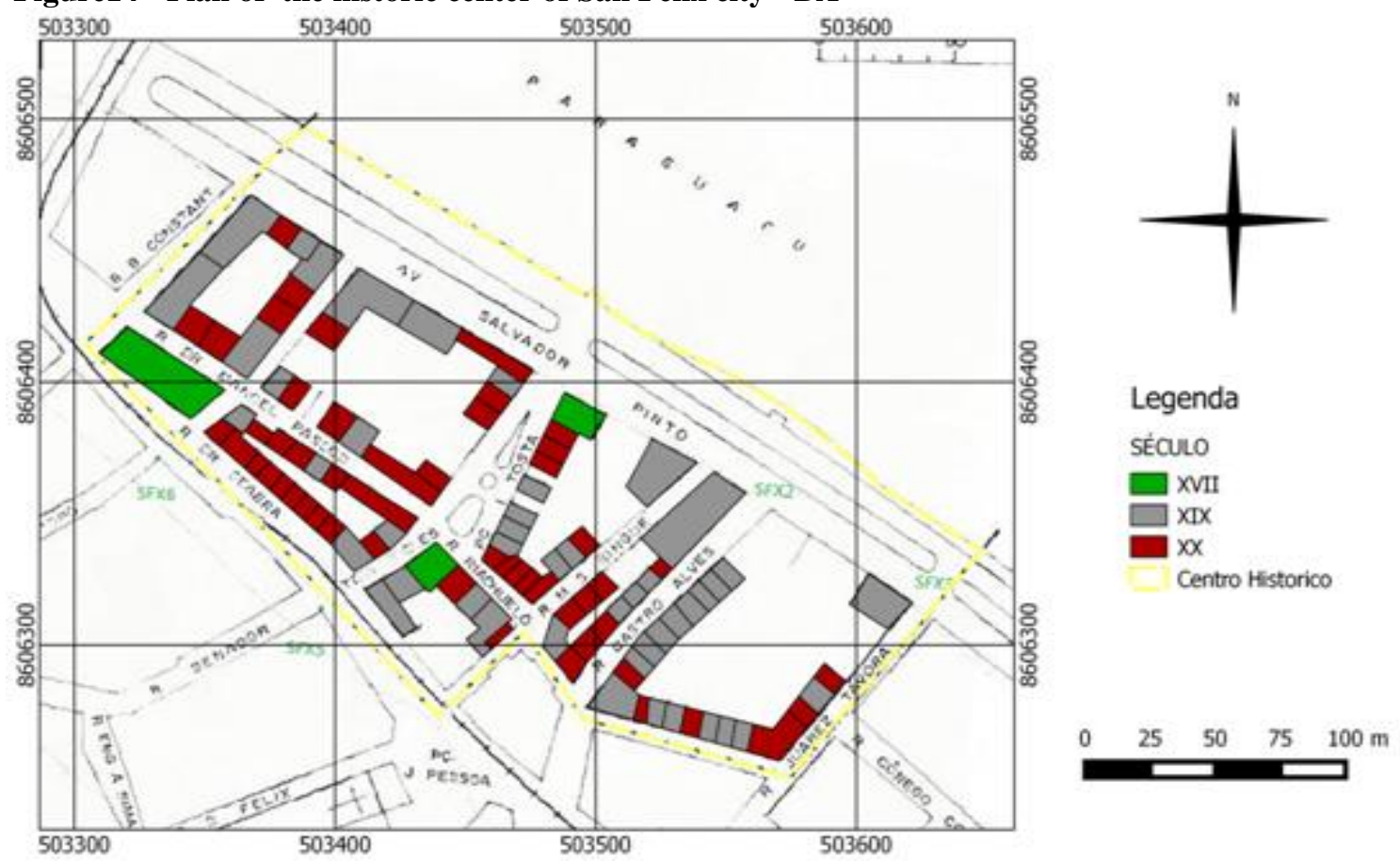

Source: IPAC, BAHIA, 1982, modified by author and geographer Marcus Fabius (UNB

In Figure 15, below, we can have the notion of urban and architectural ensemble of São Felix city.

Figure 15: panoramic view of the city of San Felix and some details of its streets

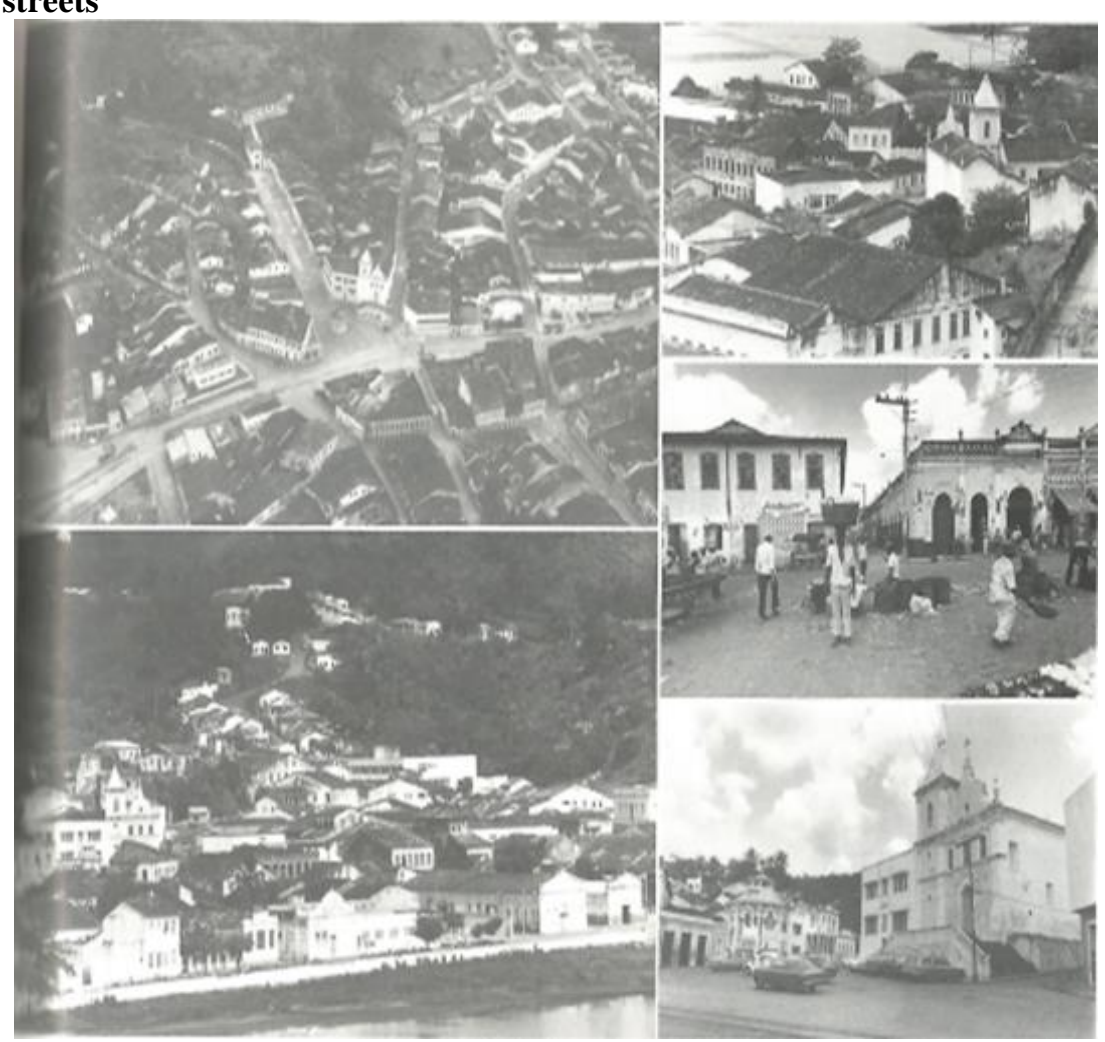

Source: IPAC's Inventory . BAHIA. 1982

The finding of an urban network in the Reconcavo Baiano corroborates the idea of regional cohesion of the territories and brings us closer to the issues that most interest us and guide this 
work. That is, the issue of temporal concurrence in the production of urban space; complementarity among them and the similarity of the built heritage. Therefore, we understand that the flows between the network of cities was not only of goods but also people and with them, the transmission of knowledge, ideas, techniques. Consequently, all this reverberated in constructive patterns that generated a built heritage of similar pattern.

\section{FINAL CONSIDERATIONS}

We found that all seven cities surveyed have similarities temporally and concurrence in the production of its urban texture, with the vast majority of its buildings erected in the $19^{\text {th }}$. century. This fact leads us to believe in a socio-spatial and socio-economic dynamics quite intense throughout this century, which in turn reveals also intense speed in the dissemination and propagation of ideas, techniques and constructive models in their urban landscapes. This reinforces the sense of what we are calling for simultaneous production of territories and a common regional spatial narrative to them all. This reinforces the sense of urban network and a very symbolic regional identity.

We emphasize that the matter of the relationship between economic dynamics and the notion of progress in the preservation of urban memory process is linked to a greater or lesser conservation of the built heritage. In this regard, certain periods of economic stagnation would be in addition to the decay of the urban setting, a form of preservation, to remove certain city the center of economic life, progress, then linked to the notion of transformation. On the other hand, the greatest intensity of economic dynamics can be overwhelming as regards the conservation of architectural sets and isolated monuments.

All cities which were surveyed have gone through different periods of economic stagnation and dynamism of certain sectors of their economy, which had impacts positively and negatively, their urban and architectural sets.

São Francisco do Conde and Jaguaripe cities are emblematic examples of the above mentioned issue. The first one suffered demeaning changes in its houses originating from the $19^{\text {th }}$. century, due to the consequences of current money and the power of transformation and urban reforms in its central area, linked to the lack of a policy of preservation of its urban memory. In the second, the opposite happened. The economic ostracism suffered by this town, especially with the implementation of Nazare city railroad in connection with its port, from the second half of that century, made Jaguaripe get in deep process of economic slowdown and, consequently, production its urban fabric was slower and less bulky, and leaving currently few copies of that century. 
However, it is necessary to point out that all surveyed cities preserved buildings of church and institutional architecture (Chapels, Parish churches and House and Jail houses), of the $17^{\text {th }}$. and $18^{\text {th }}$. centuries, plus some architectural sets of the $19^{\text {th }}$. century, especially civil architecture (residential), justifying its importance in the regional context.

Through the counting number of buildings erected in the $19^{\text {th }}$.century, we sought to refer to the idea that it is still possible to identify the peculiarities of urban and cultural landscape of the surveyed cities. Such peculiarities express themselves in similarities of shapes and temporal concurrence in the setting up of buildings, which still remain in the landscape. This process justifies new models of interventions for the preservation of urban memory of the Reconcavo Baiano region.

However, we draw attention to the bad state of conservation, degradation and ruination of most residential buildings in the urban landscape of cities on screen except Cachoeira. We notice that since the 1970s, the IPAC's inventory, has already signaled to this fact, when the characterization of properties recorded in the plans of the historic centers and those which have been inventoried and characterized in its architectural typologies, as could be seen in the above descriptions.

Given the above, we consider that the port historic towns of the Reconcavo Baiano have been neglected in the national imaginary, with regard to its importance in the historical context of urban formation in the country. They had fundamental importance, as logistical and strategic support in the battles for the province's independence and hence to consolidate the independence of Brazil, in Bahia, but did not succeed due to place in the country's history.

We believe it is still possible to reverse the current situation of degradation of the urban landscape of cities on screen, provided that there is an urgent intervention by the government in order to preserve the region and the cities on the screen.

We suggest a safeguard motion in an integrated model among municipalities, state and Union in a territorial intervention vision on a regional scale of the cultural landscape of the region. One way consortium between the municipal executive powers, so that together they can have more political clout and visibility to possible actions by the other instances of power at the state and federal level, through the Art Heritage Institute and Cultural of Bahia (IPAC) and of the Heritage Institute for National Art (IPHAN).

Finally, we indicate an intervention along with the UNESCO, in order to give the Reconcavo Baiano and its set of port historic cities, the World Heritage title for Cultural Humanity Landscape, given that that region includes all the necessary criteria to get this title, especially because it is of high cultural significance, symbolic and historical / geographical reference that is important to Bahia and Brazil. 


\section{Notes}

iThe concept of cultural landscape was adopted by UNESCO in 1992 and incorporated as a new type of recognition of cultural heritage, according to the 1972 Convention establishing the World Heritage List. To date, the sites recognized as world cultural landscape relate to rural areas, traditional agricultural systems, historic gardens and other symbolic nature of local, religious and emotional. Recognition of Rio de Janeiro will culminate in a new vision and approach on cultural properties inscribed on the World Heritage List. Available in: http://portal.iphan.gov.br

ii The doctoral research from which this article is derived, had as its main source Inventory of Bahia Cultural Assets Protection, also known as IPAC / SIC. Released the first volume in 1975, this became a technical and administrative instrument of reference for the enhancement and preservation of the cultural heritage of Bahia, to facilitate the preservation task in the state. Seven volumes make up the inventory of Bahia Cultural Assets Protection, including the printed volumes of the cultural heritage protection inventory; monuments and sites of the Reconcavo (Part I 2nd ed, v.2, 1982;... Part II 1st ed v 3), also 1982, as a theoretical and empirical reference in the whole process of our research.

iii For this article we mention only the chronological data, but the IPAC's inventory provides accurate information about the location of monuments and urban sites; analysis of photographs; name; location; situation and ambience; time of construction, architectural description; use; typological data; chronological data; architectural history and legal data in the period of research conducted by the team at the time (IPAC, BAHIA, 1982).

iv IPHAN worked on the candidacy of Rio de Janeiro as a Cultural Landscape, in partnership with the State Government and the City of Rio de Janeiro, the Roberto Marinho Foundation and the UNESCO Entrepreneurs Friends Association. In September 2009, the IPHAN delivered to UNESCO the complete dossier of the application, justifying its universal value by the interaction of its natural beauty with human intervention.

$v$ Due to the issue of space for publication of this article, we chose not to transcribe the inventory plans, just our observations from them.

vi According to the IPAC's inventory, GP acronym indicates Degree of Protection: as summation of all artistic, historical and environmental values of each real estate unit considered. Strictly speaking one monument can understand different Degrees of Protection, depending on the possible existence of parts of different values. For example, contrasting parts classifiable as GP-4 coexist with GP-1 shares or GP-2. G4, reference protection applies just spurious grafts to be eliminated. GP1 means the Direct Protection: monuments to be retained in full; GP2 - direct protection: monuments suffered successive transformations, often inappropriate, and only parts justify protection, while the rest of the building can be modified under the control of the competent authority (BAHIA, 1982a; 1982b).

\section{REFERÊNCIAS BIBLIOGRÁFICAS}

ALMEIDA, Maria Geralda de. Paisagens culturais e patrimônio cultural: Contribuições introdutórias para reflexões. In: Maneiras de ler: geografia e cultura [recurso eletrônico] / HEIDRICH, A. L.; COSTA, B. P.; PIRES, C. L. Z. (Orgs). Porto Alegre: Imprensa Livre - 
Compasso Lugar Cultura, 2013. 364 Kb ; PDF. p. 186-194.

ANDRADE, Adriano Bittencourt. $O$ outro lado da baía: a gênese de uma rede urbana colonial. Salvador: Edufba, 2013.

BAHIA. Secretaria da Indústria e Comércio. IPAC-BA - inventário de proteção do acervo cultural; monumentos e sítios do Recôncavo, I parte. $2^{a}$ edição. v. 2. Salvador, BA. 1982a.

BAHIA. Secretaria da Indústria e Comércio. IPAC-BA - inventário de proteção do acervo cultural; monumentos e sítios do Recôncavo, II parte. $1^{\text {a }}$ edição. v. 3 Salvador, BA. 1982b.

OSEKI, Jorge Hagime; PELLEGRINO, Paulo Renato Mesquita. Paisagem, sociedade e ambiente. In: PHILIPPI JUNIOR, A. et. al. (Orgs). Curso de gestão ambiental. Barueri, SP: Manole, 2004.

PAES, Maria Tereza Duarte; OLIVEIRA, Melissa Ramos da Silva (Orgs). Geografia, turismo e patrimônio cultural. São Paulo: Annablume, 2010.

SCARLATO, Francisco Capuano; COSTA, Everaldo Batista da. Geografia e patrimônio urbano: questão metodológica. In: Espaço e Geografia. v.16. n.2. Brasília: Ed. UnB, 2013.

SILVA, Luís Cláudio Requião da. Paisagem cultural do Recôncavo Baiano: Uma narrativa espacial regional a partir da análise do patrimônio urbano. Tese de Doutorado - Universidade de Brasília. Instituto de Ciências Humanas. Departamento de Geografia. Programa de PósGraduação em Geografia. Brasília, 2015.

SPIX, Johann Baptist Von; MARTIUS, Karl Friedrich Philipp Von. Através da Bahia. Bahia: Imprensa Oficial do Estado, 1916.

TAVARES, Luís Henrique Dias. História da Bahia. São Paulo: Ed. da UNESP; Salvador: Edufba, 2008.

UNESCO aprova título de Patrimônio Mundial para a Paisagem Cultural do Rio de Janeiro. Instituto do patrimônio histórico e artístico nacional. Disponível em: $<$ http://portal.iphan.gov.br/portal/montarDetalheConteudo.do?id=16727\&sigla=Noticia\&retorno=d etalheNoticia>. Acesso em 04 mar. 2015.

VILHENA, Luis dos Santos. A Bahia no século XVIII. Salvador: Editora Itapuã, 1969. 